ROCZNIKI NAUK SPOŁECZNYCH

Tom 13(49), numer $2-2021$

DOI: https://doi.org/10.18290/rns21492-8

DOROTA RYNKOWSKA

\title{
COMMUNITY SELF-HELP CENTRE AS AN INSTITUTION OF SOCIAL INTEGRATION
}

\section{INTRODUCTION}

The current demographic situation in Poland does not differ significantly from that of other European Union countries. In these countries, the phenomenon known as the aging of the population has intensified. Older people are a group that is affected by social exclusion due to low material status, poor health or disability, as well as due to the fact that the elderly are perceived by Polish society as worse. Important in the life of older people are not only family members, but also professional help and support, which sometimes turns out to be the only source of support for the elderly, lonely, sick, and disabled (Kanios, 2014).

Elderly people ${ }^{1}$ have many health problems that exacerbate over the years. Age-related deterioration of health results in limitations in everyday life, the need for support, and more frequent use of health care services.

Demographic trends indicate significant progress in the ageing of the population of Poland. This process will continue inevitably in the long-term perspective (as confirmed by the forecasts on the size and structure of the population) and will lead to a further increase in the demand for health care services and greater expenses necessary for the implementation of health care programmes (Statistics Poland, 2009). According to a 2009 survey by Statistics Poland, only one in 9 elderly persons declared that they did not experience long-term health problems and did not suffer from chronic diseases, while the vast majority (nearly 90\%) declared having such problems (Statistics

Dr DOROTA RYNKOWSKA — assistant professor, University of Rzeszów, Institute of Social Science; address for correspondence: al. Rejtana 16c, 35-959 Rzeszów; e-mail: drynkowska@ur.edu.pl; ORCID: https://orcid.org/0000-0002-2747-7373.

${ }^{1}$ In this paper old age is defined as 60 years of age or older, according to a recommendation by WHO. 
Poland, 2009). Moreover, every third elderly person reported difficulties with everyday activities related to personal care and hygiene. Seniors had the greatest problems with getting into and out of bed, getting up from a chair, personal hygiene, and getting dressed and undressing. Due to the lack of support from other people or the lack of special equipment or devices, nearly half of the elderly had to cope with inconveniences in everyday life on their own. Health problems also reduce the ability of the elderly to run a household. First of all, elderly people are unable to perform occasional, more strenuous housework, but also-although to a lesser extent - to go shopping, prepare meals or deal with administrative and financial matters. Data from surveys indicate that more than $60 \%$ of all seniors have limitations concerning basic household activities. Almost one in six elderly people experiencing limitations in running their household did not have any support and had to cope with problems on their own. As indicated by the analysis of the Central Statistical Office report on the quality of life of the elderly in Poland, seniors in Poland assessed their health as worse compared to the elderly in the EU-28. According to the adopted estimates, the life expectancy of people aged 65 in Poland was slightly shorter than the EU-28 average (1 year for women, 2 years for men). Similar estimates were made for the expected life.

According to Anthony Giddens:

[...] the perception of the progress of ageing as obvious and natural is gradually changing; the progress in medical science and diet has shown that it is possible to eliminate or greatly reduce most of the symptoms of ageing that used to be seen as unavoidable. Due to better diet, hygiene, and health care the average life expectancy is much longer that it was even a hundred years ago (Giddens, 2006, p. 185).

Considering the forecasted significant increase in the number of elderly people over the next 20 years in Poland, the problem of independent living in this subpopulation should be expected to be more serious, especially among seniors requiring different forms of assistance such as care, medical treatment and rehabilitation (Duda, 2012). The demographic situation and the health status of the population are direct factors that have a significant impact on trends in the demand for health care services provided by inpatient care facilities (hospitals, residential care facilities), outpatient health care, paramedic services, as well as by social welfare institutions, both in the form of day care and residential care.

The situation of the elderly, outlined above, also includes issues related to the area of seniors' isolation. Social exclusion and marginalization is a constant 
in the daily life of many older people. It is one of the serious and still unresolved social problems. Demographic changes and the aging society are a challenge for local communities, which should create conditions for the activation and social integration of older people in their place of residence. Therefore, a new approach is necessary-especially of local communities, which should popularize activities for the involvement of active older people in social work, enable them to acquire new skills in the field of social integration of people aged $60+$, and also effectively help in eliminating barriers and problems that they face. there are seniors using the services of environmental help (Halicki, Halicka, 2002).

\section{GENERAL AND SPECIALIST CARE SERVICES}

As already mentioned, the rapid ageing of the Polish population leaves no doubt that in the coming decade the social assistance system will have to focus on broadly defined care, nursing and rehabilitation. Due to the ongoing pandemic caused by the spreading coronavirus (SARS-CoV-2) responsible for the COVID-19 disease, the current reality and health of Polish society have contributed to radical changes in the health of all citizens. A particularly significant change has affected seniors as a group at high-risk of contracting COVID-19 and the severe course of the disease, and numerous complications requiring comprehensive care and rehabilitation.

Because of the current circumstances, family members are often unable to provide care for their elderly, ill, disabled relatives, mainly due to employment-related duties (Duda, 2008). Specialist social services are an important element of activities supporting the family in such a situation, including professional care and nursing of the elderly who are dependent and disabled. Apart from cash benefits, the system of social assistance in Poland offers another important form of support to the elderly, dependent and disabled people, i.e. services organized by Social Assistance Centres. Services include general and specialist care, i.e. tailored to the specific needs of a disabled person, provided, for example, by physiotherapists, medical professionals, etc. at the home of the beneficiary or outside it. These services are addressed mainly to people living alone who need support from other people because of their old age and illness (Krzyszkowski, 2011).

In the Polish system of social assistance issues related to care services for seniors and other people are specified in Ustawa z dnia 12 marca $2004 \mathrm{r}$. 
o pomocy społecznej [Act on Social Assistance of March 12, 2004], and the Rozporządzenie Ministra Polityki Społecznej z dnia 22 września 2005 r. w sprawie specjalistycznych usług opiekuńczych [Regulation of the Minister of Social Policy of September 22, 2005 on specialist care services]. Assistance in the form of general and specialist care services is provided to a person in need running a household alone, who due to age, illness or other reasons requires support from other people, or a person who needs support, but family members, or a cohabiting spouse, descendants, or ascendants cannot provide such support, or a person to meet his or her specific needs resulting from the type of illness or disability. Services can be provided at the home of the beneficiary who needs assistance, at support centres (community self-help centres), self-help clubs, and day care centres.

Care services are defined as a non-cash form of assistance provided to a person in their place of residence who, due to illness, age or other reasons, requires the assistance of another person, but is deprived of it. Care services include helping beneficiaries with their personal hygiene (washing, bathing, dressing, dosing medications), care recommended by a doctor, everyday tasks (shopping, preparation of meals, laundry, dealing with official matters), and even ensuring contact with the community as much as possible.

Care services are a statutory and compulsory task of the local administration unit relevant for the place of residence of the person who needs them (either a person running a household alone or a family member). Services are granted when the elderly person has no relatives who could look after him or her, such as a spouse, ascendants and descendants, or these relatives are unable to provide care. The main purpose of services provided at the home of an elderly person is to enable them to function in their community. Adequate provision of services should help eliminate limitations and barriers to integration with the community, as well as prevent deterioration or, if possible, improve the quality of life.

Care services also have other objectives: to improve the mental health of the elderly, to prevent complications associated with illness or prolonged immobilization, and to sustain or increase the independence and activity of the beneficiary. Care services may also be provided by social assistance institutions, non-governmental organizations specializing in this field, and businesses. In each of these cases, it is important to activate and support the elderly person, instead of doing everything for them. It is also important to cooperate with the close environment of the senior person (Balon et al., 2015, pp. 5-6). 
The Act on Social Assistance defines a detailed procedure to be followed when granting services and determining their range. Before assistance is granted, the potential beneficiary has to submit a relevant application. This can be done in person on the basis of a written application or over the phone. Then, within a maximum of 14 working days, a care needs assessment is conducted for the family, and based on it the economic and social status of the applicant is analysed, and necessary documents are collected, including a health certificate (Rynkowska, 2019, p. 99). During the needs assessment, it is very important to establish personal details and addresses of people that have a maintenance obligation towards the applicant. It is necessary to conduct an interview with these people, and based on it determine the type and level of assistance for which the applicant is eligible. After collecting information and analyzing the status of the applicant, the level and type of care services are determined on an individual basis. At the next step a positive or negative decision on granting service is issued (Tobiasz-Adamczyk, 2000).

Care services are a paid form of assistance and costs are covered by people who receive them, or their family. The cost of services and the terms on which they are granted are established by the local community council in a relevant resolution. Therefore, both the cost and form of assistance may differ between regions. However, there may be some exemptions from payment if the expenses of a person or a family applying for services are very high and their income is low. The fact that someone cannot afford to pay for the care services does not mean that these people cannot use them. Importantly, care services may be provided 7 days a week if the eligible person requires this level of care. These services are provided by community carers with appropriate training.

Specialist care services are provided to people with mental disorders. The regulation of the Minister of Social Policy on specialist care services of September 22, 2005 $5^{2}$ and the Act on Social Assistance of March 12, 2004 ${ }^{3}$ specify the types of services for the mentally ill, costs of services, exemptions from payments, and the qualifications of staff providing specialist care services. The types of services depend on the type of illness or disability. The main goal of these services is to teach and enhance skills that promote independent living of the patient in his or her community.

\footnotetext{
${ }^{2}$ Regulation of the Minister of Social Policy of September 22, 2005 on specialist care services.

${ }^{3}$ Act of March 12, 2004 on Social Assistance (Dziennik Ustaw [Journal of Laws] no. 64 item 593, as amended), Article 50, clauses 1-4.
} 
This form of assistance may be provided to the mentally ill, intellectually disabled people, and people with mental disorders who require care. The aim of these services is to improve the quality of life of people with mental disorders. The range of care services is tailored to a specific disorder. Specialist care services for people with mental disorders are also paid for, and, as a rule, the rates are higher than those for general care services. Rates per hour of service are determined by the social assistance centre relevant for the beneficiary's place of residence.

Services also include physical rehabilitation prescribed by a specialist, which is not financed by the National Health Fund. A caregiver can also help in establishing proper relations with family members, the community, friends, and in handling household duties such as paying rent, adaptation of the home, minor repairs and the elimination of architectural barriers. Assistance may also include help in official matters, cooperation with the family in resolving conflicts and emergency situations, help in finding suitable employment or alternative activity, e.g. in occupational therapy establishments, occupational therapy workshops, community integration clubs and centres, or community self-help centres. Another form of assistance is help in planning home budgets and expenses, how to work with money, how to obtain reliefs in payments, and achieving financial independence. Nursing services include help in ordering and buying medications, making appointments for doctors and diagnostic tests. A caregiver also helps with transport to rehabilitation centres and health care facilities, as well as provides assistance in obtaining specialist equipment, orthopaedic aids and medical materials.

Specialist care services for people with mental disorders are granted to the beneficiary upon application, and the level of services (in hours) and type of assistance have to be specified in a relevant health certificate from a doctor. After conducting the care needs assessment, collecting information on family income, and calculating income per capita, the cost of services is determined. The relevant table in the regulation presents the brackets of income for a family or a person running a household alone and defines the payment rates. Care services are free of charge if monthly income in a family or in a singleperson household is not higher than PLN 701 per capita, in accordance with the Act on Social Assistance, Article 8 clause 1(1). 


\section{OFFER OF THE COMMUNITY SELF-HELP CENTRE IN KRAŚNIK -OVERVIEW AND ANALYSIS}

People who, due to their old age, illness or disability, require some level of care and assistance in satisfying their basic needs, apart from care services and specialist care services, are offered services provided by support institutions, e.g. the community self-help centre. The goals and principles of operation of CSHCs are regulated in Poland by the Ustawa z dnia 19 sierpnia 1994 roku o ochronie zdrowia psychicznego, Dz.U. of 1994, No. 111, item 3350, [Act of August 19, 1994 on mental health protection, Dz.U. of 1994, No. 111, item 3350] and the Act on Social Assistance, as amended, which set forth general priorities and purpose for the operation of support centres for people with disabilities as an alternative to inpatient hospital treatment.

The provisions of the Act on Social Assistance and the Regulation on CSHCs issued on its basis are fundamental for the establishment and operation of community self-help centres. Such centres are among several types of establishment providing support to people with mental disorders, specified in Article 51a clause 1 of the aforementioned Act. The management and development of the infrastructure in such centres is one of the tasks delegated by the central government to municipalities (Article 18 clause 1(5) of this Act) and counties (Article 20 clause 1(2)). Pursuant to Article 51 clauses 2 and 3, and 51a clauses 1 and 3 of the Act on Social Assistance, the community self-help centre is an organizational unit providing daily care, which may also offer residential care financed from the state budget (an eligible person may stay there for no longer than 8 months per calendar year).

The offer for this specialist support option includes basic educational, nursing, and recreational and cultural services. The most common institutions of this type include community self-help centres for people with mental disorders, day homes for adolescents with physical and/or intellectual disabilities, day homes for people with Alzheimer's disease, day homes for the elderly, night accommodation, assisted living flats, and self-help clubs (Sikora, 2005).

Community self-help centres are dedicated for people with intellectual disabilities, chronic mental diseases, those with multiple disabilities, as well as for the elderly. Their primary role is to provide psychiatric care to patients, including psychotherapy, consultations and pharmacotherapy (Załuska, 2015). These centres also offer social rehabilitation, training for independent living, and prepare, if possible, the patient to start work. Moreover, these centres offer broadly defined occupational therapy. There are four types of community 
centres: A, B, C and D. Type A centres are dedicated for people with chronic mental illness, type $\mathrm{B}$ for people with intellectual disability, type $\mathrm{C}$ for people with other chronic mental disorders, and type D for people with multiple disabilities, autism, and autism spectrum disorders (Kaszyński, 2005).

These care centres operate based on Article 25 of the Act on Social Assistance. They are governed by local administration authorities (county or municipality), but may also be run by foundations or other NGOs. The operation of these centres is financed from an annual subsidy allocated for individual beneficiaries, granted by a province governor. A day care centre is open for beneficiaries for 8 hours per day, from Monday to Friday. The type and number of personnel depends on the type of care centre and number of beneficiaries. The therapeutic offer includes: music therapy, training in social skills, communication and assertiveness, occupational therapy, physical activities, arts and crafts, manual therapy, and other activities tailored to the capacities and needs of beneficiaries.

In order to be admitted to a community self-help centre, a relevant application should be submitted along with a certificate from a family doctor and a neurologist or psychiatrist, specifying the type of centre recommended for the patient. A complete application should also include a certificate stating the degree of disability. During the first three months, an activating and supporting plan is prepared for a beneficiary (Wideł, 2011, pp. 88-90).

The Community Self-help Centre in Kraśnik operates on the basis of the Resolution of the County Council no. LI-227/2006 of July 26, 2006 regarding the establishment of a support centre for people with mental disorders and is located in the building at Grunwaldzka street no. 6 in Kraśnik. The forms and outcomes of operations carried out by the Community Self-help Centre in Kraśnik in 2020 are presented in relevant official documents (annual report, regulations, statutes, in-house records) provided by the director of the facility. Some activities were provided only until March 12, 2020 and suspended because of COVID-19 epidemics, and this had a significant impact on the implementation of individual offers. Services provided by the CSHC are dedicated to adolescents, adults and the elderly. The operation of the CSHC in Kraśnik has the following aims: to support beneficiaries and their families in the field of mental and physical health, to create conditions for acquiring the basic skills necessary for everyday life, to improve acquired skills, to maintain and develop skills necessary for independent living, to ensure a sense of security for beneficiaries, to integrate beneficiaries with their community, and to develop the personal interests of beneficiaries. To achieve these, a team of employees at the CSHC prepared 
personalized support and rehabilitation plans tailored to the needs and mental and physical capacities of each beneficiary.

The CSHC is a day care centre for adult beneficiaries with mental disorders living in Kraśnik county, who, due to the impairment of some physical and/or mental capacities, need help to better adapt to life in their family and community, and in particular to enhance their personal potential and independence. It is a day care facility for 54 people, including those who have chronic mental illness (type A, 8 people), people with intellectual disability (42 people, type B), as well as beneficiaries with multiple disabilities (4 people, type C). Chronic mental disorders for which beneficiaries were eligible for admission to the CSHC in Kraśnik included organic mood disorders (1 person), conditions after aneurysm rupture (1 person), depressive disorders (1 person) and organic impairment of intellectual performance (1 person). By the end of December 2020 there were 58 decisions granting day care. On 31 of December 2020 there were 54 beneficiaries attending the CSHC. In 2020 four beneficiaries dropped out: one for personal reasons, one person died, one started vocational training, and another person returned home.

Table 1. Age and number of beneficiaries (on December 31, 2020)

\begin{tabular}{|l|c|c|c|c|}
\hline $\begin{array}{c}\text { Age } \\
\text { range }\end{array}$ & $\begin{array}{c}\text { Number } \\
\text { of beneficiaries } \\
\text { in the age range }\end{array}$ & $\begin{array}{c}\text { Number } \\
\text { of beneficiaries } \\
\text { Type A }\end{array}$ & $\begin{array}{c}\text { Number } \\
\text { of beneficiaries } \\
\text { Type B }\end{array}$ & $\begin{array}{c}\text { Number } \\
\text { of beneficiaries } \\
\text { Type C }\end{array}$ \\
\hline 18-30 years & 8 & - & 7 & 1 \\
\hline $31-40$ years & 21 & 3 & 18 & - \\
\hline $41-50$ years & 17 & 5 & 12 & - \\
\hline $51-60$ years & 3 & - & 3 & - \\
\hline $61-70$ years & 2 & - & 1 & - \\
\hline $71-80$ years & 3 & - & - & - \\
\hline $81-90$ years & - & - & - & 4 \\
\hline $91-100$ years & - & - & 42 & - \\
\hline $\begin{array}{l}100 \text { years } \\
\text { and older }\end{array}$ & - & 8 & & - \\
\hline Total & 54 & & & \\
\hline
\end{tabular}

Source: author's own analysis. 
The CSHC provides services on working days, from Monday to Friday, between 7:30 and 15:30. Within this 8-hour schedule, 6 hours are dedicated for therapy, and another 2 hours for maintenance work, preparation for activities, record keeping, and provision of care for beneficiaries during travel to join activities and return after the end of activities. The operation of the CSHC is focused primarily on helping beneficiaries to cope with difficult life situations, as well as enhance social and cultural integration. Thanks to this, the beneficiaries understand and accept their own imperfections better, and thus are more integrated with their community in social and emotional terms. Specialist services are provided by the CSHC in the form of individual or group sessions for social skills training, during which beneficiaries learn, develop and preserve skills necessary for daily functioning and social relations.

The services are tailored to the individual needs and psychophysical capacities of beneficiaries, and their type and range are defined in a personalized support and activation plan. This plan is prepared by a dedicated team that consists of the director of the facility and other specialists in specific areas. Beneficiaries of the CSHC in Kraśnik are provided with one meal a day and soft drinks, appropriate therapeutic and rehabilitation services, the opportunity to participate in therapeutic activities outside the CSHC, proper and safe sanitary and hygienic conditions, protection of privacy and protection of freedom of conscience and religion, appropriate standard of services compliant with regulations, and a safe environment. Additionally, the CSHC offers beneficiaries daily transport services, and 28 beneficiaries from the municipalities in the Kraśnik region are taken to the CSHC for activities and then back home.

Table 2. Transportation of CSHC's beneficiaries

\begin{tabular}{|c|c|c|}
\hline No. & Municipality & Number \\
\hline 1 & Kraśnik (town) & 11 \\
\hline 2 & Zakrzówek municipality & 3 \\
\hline 3 & Szastarka municipality & 1 \\
\hline 4 & Gościeradów municipality & 2 \\
\hline 5 & Trzydnik Duży municipality & 4 \\
\hline 6 & Dzierzkowice municipality & 3 \\
\hline 7 & Wilkołaz municipality & 1 \\
\hline 8 & Stróża municipality & 28 \\
\hline Total & & \\
\hline
\end{tabular}

Source: author's own analysis. 
The scope of the CSHC's operation in 2020 included, among other services, occupational therapy in the following areas: IT education, arts and crafts, art therapy, cooking, movement therapy, and life skills and social skills education. An important aspect of the CSHC's operation is to teach its beneficiaries lifestyle functionality during individual and group sessions. Activities provided by the CSHC were adjusted to the capacities and needs of beneficiaries. In 2020 the CSHC offered its beneficiaries education in the following areas, life skills education-mainly teaching activities necessary for day-to-day life, but also in other aspects. This included education in personal care and hygiene, operation of household appliances, working with money, school skills, dealing with public institutions (banks, post offices, job centres, libraries, local social welfare centres, centres for family support), safety rules, other practical skills. Education in interpersonal skills and problem-solving, which is a continuation of activities by organizing individual and group sessions and using specific methods such as brainstorming, debates, chats, integrating games and movie screenings. These activities included teaching ways of spending leisure time and were realized in each specific area. Beneficiaries learned how to manage their leisure time effectively; leisure activities included music therapy, aromatherapy, therapy through reading fairy tales, watching movies, outings, walks, group visits to different venues in Kraśnik, team games enhancing integration-indoor or outdoor, conversations to support either group or individuals, playing board games, educational games, arranging puzzles, doing crosswords, quizzes, solving puzzles, brain teasers, tending plants indoor or in the garden, education through reading books, guides, gardening magazines, and watching movies about nature. Education in interpersonal skills. Topic: 'What makes relations easier/more difficult?,' 'Expressing judgements in messages with a focus on YOU, and expressing opinions in messages with a focus on I.' Aims: To define signals that distract or facilitate communication; replacing statements focused on YOU with those focused on I (ME) - replacing judgements with opinions. Form of activity: individual, in groups. Methods: chat to explain the concepts of communication, distracting signals, signals facilitating communication; the therapist gives examples of signals that distract or facilitate communication. Education in team skills. Aims: To make participants aware of the value of team work, experiencing success and failure as a team; focus on fun, integration of participants and not on their competition; to improve the ability to cooperate in a group. Methods: chat-to explain the benefits of team work. Form: in a group or individual. Topic: 'Tell me something about yourself,' 
'Desert island.' Education in problem-solving skills. Aims: to teach and improve skills in the constructive solving of conflicts and problems, making the right decisions; to improve the ability to recognize and name emotions associated with interpersonal conflicts. Form: individual, in groups. Methods: chat-to explain what conflict is, to discuss the reactions of people involved in conflict, role play 'Much ado about nothing,' an integrating game 'Two heads are better than one.'

Teaching assertiveness. Aims: to teach basic information about an assertive attitude; to develop assertiveness in beneficiaries, to teach them how to recognize their own behaviours, make them aware of the mechanism of group pressure and how to say 'no,' to teach them the difference between assertive, submissive and aggressive behaviours. Form: individual, in groups. Methods: mini-lecture-explanation of definitions, discussion about recognizing specific behaviours, presentation of the topic of classes, 'Assertive behaviour-how to consciously and boldly say NO.' Topic: Four types of behaviour-a caregiver explains each type of behaviour and beneficiaries give relevant examples. Role plays to practice saying NO.

Education in using polite phrases. Aims: improving skills in using polite phrases in everyday life, learning the meaning of polite phrases. Participants practice by listening and trying to understand their interlocutor. Form: in a group. Methods: conversation, explanation, discussion, work with text. Education in stress management. Aims: To explain how stress is experienced; To teach task-oriented methods of coping in stressful circumstances. Form: exercise 1 -individual, exercise 2-individual and teams of 3 people. Methods: mini-lecture, the student stress scale was used, describing events in human life that may be very stressful-events are scored 1 to 10 ; discussion, work with text. Training for self-esteem and empowerment. Aims: To develop self-awareness and the ability to see good and strong points in oneself and other people, and how to talk about it. Form: in a group or individual. Methods: chat, exercises.

Other services provided by the facility include psychological counselling for individuals and pedagogical counselling for groups, social work, empowering the involvement of beneficiaries in decision-making at the CSHC, facilitating access to necessary health care services, meetings with a psychiatrist (twice a month, services as part of private psychiatric practice), and social and professional activation of people with disabilities through the participation of two beneficiaries of the CSHC in the project implemented by the Centre for Family Support in Kraśnik 'You can make it if you want,' implementation of the project 'Let's be active together' in partnership with 
the Successful Leaders Foundation (free rehabilitation for 8 beneficiaries, 10 hours per person). Rehabilitation support includes manual therapy and relaxation exercises. The Regional Social Welfare Centre (ROPS) in Lublin provided funding (PLN 10.400.00) for the swimming project 'Ale popłynęli' in partnership with the 'Res sacra Miser' Association for 15 beneficiaries. Beneficiaries took part in swimming activities in an open air pool during the summer and were given snacks and drinks (project financed by ROPS in Lublin, PLN 1125.00). Dog therapy ('Dogoterapia'), a project implemented in partnership with the 'Res sacra Miser' Association for 5 beneficiaries, (financed by ROPS in Lublin, PLN 1500.00).

Table 3. Number of beneficiaries taking part in specific activities in each month of 2020

\begin{tabular}{|c|c|c|c|c|c|c|c|c|c|c|c|c|c|}
\hline Month & $\begin{array}{l}\vec{\Xi} \\
\stackrel{\Xi}{\Xi}\end{array}$ & 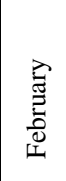 & 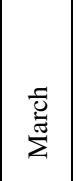 & $\overline{\mathrm{a}}$ & $\sum^{\mathrm{a}}$ & $\stackrel{\Xi}{\Xi}$ & હ & $\begin{array}{l}\bar{v} \\
\underline{E_{0}} \\
\vec{z}\end{array}$ & $\begin{array}{l}\overline{0} \\
\text { है } \\
\text { गे } \\
\text { ปे }\end{array}$ & $\begin{array}{l}\overline{0} \\
\overline{0} \\
\overline{0} \\
0\end{array}$ & $\begin{array}{l}\bar{\Xi} \\
\text { है } \\
\text { Dे } \\
\text { z }\end{array}$ & 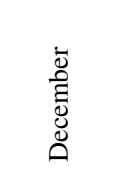 & $\begin{array}{c}\text { Mean } \\
\text { number of } \\
\text { beneficiaries } \\
\text { in } 2020\end{array}$ \\
\hline $\begin{array}{l}\text { Learning } \\
\text { IT skills }\end{array}$ & 5.33 & 8.60 & 2.50 & 0 & 0 & 3.24 & 4.00 & 5.19 & 4.73 & 4.18 & 0 & 2.14 & 3.33 \\
\hline $\begin{array}{l}\text { Arts } \\
\text { and crafts }\end{array}$ & 5.80 & 4.60 & 2.30 & 0 & 0 & 4.10 & 4.00 & 3.60 & 5.50 & 2.50 & 0 & 2.10 & 2.90 \\
\hline $\begin{array}{l}\text { Art } \\
\text { therapy }\end{array}$ & 6.19 & 8.35 & 2.59 & 0 & 0 & 4.85 & 3.83 & 7.24 & 4.30 & 1.95 & 0 & 2.18 & 3.45 \\
\hline $\begin{array}{l}\text { Life skills } \\
\text { education }\end{array}$ & 6.57 & 5.10 & 1.60 & 0 & 0 & 5.85 & 4.61 & 4.00 & 3.86 & 2.68 & 0 & 3.30 & 3.13 \\
\hline $\begin{array}{l}\text { Social } \\
\text { skills } \\
\text { education }\end{array}$ & 7.20 & 6.60 & 2.90 & 0 & 0 & 3.10 & 4.90 & 2.40 & 6.10 & 2.40 & 0 & 1.40 & 3.10 \\
\hline $\begin{array}{l}\text { Cooking } \\
\text { classes }\end{array}$ & 7.61 & 7.35 & 1.81 & 0 & 0 & 3.47 & 7.17 & 4.67 & 4.86 & 2.72 & 0 & 3.13 & 3.57 \\
\hline $\begin{array}{l}\text { Movement } \\
\text { therapy }\end{array}$ & 13.33 & 22.25 & 21.13 & 0 & 0 & 7.52 & 6.70 & 3.33 & 7.55 & 6.95 & 0 & $\begin{array}{c}\text { Educator } \\
\text { on leave } \\
\text { after } \\
\text { maternity } \\
\text { leave }\end{array}$ & 7.40 \\
\hline
\end{tabular}

Source: author's own analysis. 


\section{CONCLUSIONS}

The elderly, and people with disabilities and/or mental disorders need treatment tailored to their health problems, as well as appropriate psychotherapy and rehabilitation. All activities promoting independent living and integration with the community are of particular importance in the recovery process. Community self-help centres are one of the best and fastest evolving forms of support in Poland for people with mental disorders, physical disabilities and the elderly.

Community Self-help Centres create opportunities for personal development and provide support in a broad sense, with a focus on physical and mental health, as well as social functioning and employment. Thanks to various forms of therapy, beneficiaries learn how to cooperate and live in a group. A large range of attractive activities, an appropriate level of rehabilitation, and wide contact with people from the community greatly facilitate adaptation to changing life circumstances, and help beneficiaries to understand their illness and have a dignified life despite disability.

The main goal of the Community Self-help Centre is to enhance personal potential and independence in life, as well as promote the social integration of beneficiaries, which, as shown by the wide offer of the facility, is implemented with great success and commitment of the staff. The main objective is to activate beneficiaries by involving them in a range of classes, training sessions using modern methods, and forms and techniques of work in the therapeutic process. In 2020, the Community Self-Help Centre in Kraśnik carried out its tasks in accordance with the Act on Social Assistance, the Mental Health Act, and the Regulation of the Minister of Labour and Social Policy on community self-help centres. The workshops, which extended the range of therapeutic services, enjoyed great interest among the beneficiaries. New methods of work were implemented to support people with mental disorders, including those with multiple disabilities, and this approach significantly improved the functioning of beneficiaries in the family and in the local community. The beneficiaries and their families received help and support in health-related issues and solving problems in their family life. The support was also provided to beneficiaries and their families during the COVID-19 pandemic. Food packages, lunches, and educational materials were delivered to beneficiaries during that time. Rehabilitation was offered under projects in partnership with non-governmental organizations, which allowed the beneficiaries to prevent deterioration of health and improve their motor and 
manual capacity, strengthen muscles, and stimulate positive attitudes towards this type of activity. Outings, events and integration meetings for beneficiaries organized either on-site at the centre or off-site increased the interest of the local community in the operation of the CSHC in Kraśnik, which offers a variety of support services for the elderly, the disabled and dependent individuals. Not all goals set for 2020 in the operational plan were fully implemented in the reporting period due to the COVID-19 pandemic and relevant restrictions. For this reason, some items from the plan were moved for implementation in 2021.

Community Self-Help Centres are primarily aimed at helping, in accordance with the Act on Social Assistance, in overcoming difficult life situations, but also providing emotional support, eliminating social exclusion by undertaking integration and activating activities, including the elderly, disabled and dependent in the daily functioning of this type of outlets.

\section{BIBLIOGRAPHY}

Balon K., Staręga-Piasek J., Rutkiewicz G., Stec K., Szmaglińska I., Zielony M. (2018), Standard ustug opiekuńczych świadczonych dla osób starszych w miejscu zamieszkania (Projekt 1.18: Tworzenie i rozwijanie standardów usług pomocy i integracji społecznej jest współfinansowany ze środków Unii Europejskiej w ramach Europejskiego Funduszu Społecznego).

Błędowski P., Szatur-Jaworska B., Szweda-Lewandowska Z., Kubicki P. (2012), Raport na temat sytuacji osób starszych w Polsce, Warszawa: Instytut Pracy i Spraw Socjalnych.

Duda M. (2008), Wprowadzenie, [in:] M. Duda (Ed.), Rodzina wobec zagrożeń, Kraków: Wydawnictwo Naukowe PAT.

Giddens A. (2006), Socjologia, Warszawa: PWN.

Główny Urząd Statystyczny. Departament Badań Społecznych (2020), Jakość życia osób starszych $w$ Polsce. Raport z badań, Warszawa: GUS.

Halicka M., Halicki J. (2002), Integracja społeczna i aktywność ludzi starszych, [in:] B. Synak (Ed.), Polska starość, Gdańsk: Wydawnictwo Uniwersytetu Gdańskiego, pp. 189-201.

Kanios A. (2014), Postawy osób starszych wobec własnej starości, [in:] K. Denek, A. Kamińska, P. Olesniewicz (Eds.), Edukacja jutra. Od uniwersytetu do starości. Aspekty edukacji osób dorostych, Sosnowiec: Oficyna Wydawnicza Humanitas, pp. 241-245.

Kaszyński H. (2005), Przeciwdziałanie wykluczeniu społeczno-zawodowemu chorujących psychicznie w Polsce, [in:] A. Cechnicki, H. Kaszyński (Eds.), Praca, zdrowie psychiczne, gospodarka spoteczna, Kraków: Krakowska Inicjatywa na Rzecz Gospodarki Społecznej COGITO, pp. 36-41.

Krzyszkowski J. (2011), Osoby starsze, [in:] R. Szarfenberg (Eds.), Krajowy raport badawczy Pomoc i integracja spoteczna wobec wybranych grup - diagnoza standaryzacji ustug i modeli instytucji, Warszawa: WRZOS, www.wrzos.org.pl/projekt1.18/download/KRB_wersja\%20os tateczna.pdf [accessed: August 7, 2021]. 
Rozporządzenie Ministra Pracy i Polityki Społecznej z dnia 9 grudnia 2010 r. w sprawie środowiskowych domów samopomocy, Dz.U. of 2009, No. 175, item 132 as amended.

Rozporządzenie Ministra Polityki Społecznej z dnia 22 września 2005 r. w sprawie specjalistycznych usług opiekuńczych, Dz.U. No 189, items 1597-1598.

Rynkowska D. (2019), Rola opiekunów w procesie wsparcia podopiecznych w świetle działalności opiekuńczej Polskiego Czerwonego Krzyża, Rzeszów: Wydawnictwo Uniwersytetu Rzeszowskiego.

Sikora P. (2005), Formy wsparcia i opieki, [in:] J. Brągiel, S. Sikora (Eds.), Formy opieki, wychowania $i$ wsparcia $w$ zrefundowanym systemie pomocy społecznej, Opole: Wydawnictwo Uniwersytetu Opolskiego, pp. 145-149.

Tobiasz-Adamczyk B. (2000), Wybrane elementy socjologii zdrowia i choroby, Kraków: Wydawnictwo Uniwersytetu Jagiellońskiego.

Ustawa z dnia 19 sierpnia 1994 roku o ochronie zdrowia psychicznego, Dz.U. of 1994, No. 111, item 3350 .

Ustawa z dnia 12 marca 2004 r. o pomocy społecznej, Dz.U. No 64, item 593 as amended (Article 18, point 1).

Wideł E. (2011), Wsparcie społeczne dla osób z zaburzeniami psychicznymi, [in:] A. Kwak, E. Wyrwich-Hejduk (Eds.), W kręgu zagadnień pracy socjalnej, Warszawa: Wydawnictwo APS, pp. 88-90.

Załuska M. (2015), Opieka zdrowotna $i$ wsparcie społeczne dla osób z zaburzeniami psychicznymi. Informator dla chorujacych, ich rodzin i przyjaciót, Warszawa: Biuro Rzecznika Praw Obywatelskich.

\section{Websites}

https://stat.gov.pl/cps/rde/xbcr/gus/ZO_stan_zdrowia_2009.pdf [accessed: April 1, 2021].

https://www.gov.pl/web/rodzina/srodowiskowe-domy-samopomocy-informator [accessed: April 1, 2021].

https://www.rpo.gov.pl/pl/content/rpo-system-srodowiskowego-wsparcia-osob-z-zaburzeniamipsychicznymi-wymaga-zmian [accessed: April 1, 2021].

\section{COMMUNITY SELF-HELP CENTRE AS AN INSTITUTION OF SOCIAL INTEGRATION}

\section{Summary}

Demographic ageing of the society has a direct impact on the number of dependent people who need assistance from specialized institutions. People in a difficult life situation who need support, e.g. daily or live-in/residential care due to their old age, illness or disability, can take advantage of the offer of institutions providing social assistance services. Among such institutions are community self-help centres (CSHC, in Polish 'środowiskowy dom samopomocy') governed by the Ministry of Social Policy and organized by units of local administration to provide care, nursing and assistance services. The aim of this paper is to present the operation, scope of assistance and the offer of the Community Self-help Centre in Kraśnik, and to show good practices in providing services to the elderly, dependent and disabled people based on the analysis of official documents (statutes, regulations, and an annual report prepared by this centre for 2020).

Keywords: senior; social support; support institution; social integration. 


\title{
ŚRODOWISKOWY DOM SAMOPOMOCY JAKO INSTYTUCJA INTEGRACJI SPOŁECZNEJ
}

\author{
Streszczenie
}

Demograficzne starzenie się społeczeństwa wpływa bezpośrednio na liczbę osób niesamodzielnych i potrzebujących wsparcia specjalistycznych instytucji. Osoby znajdujące się w trudnej sytuacji życiowej i wymagające wsparcia, opieki (częściowej lub całodobowej) z powodu wieku, choroby lub niepełnosprawności mogą skorzystać z oferty jednostek świadczących usługi pomocy społecznej. Jednym z nich jest Środowiskowy Dom Samopomocy (ŚDS) - jednostka organizacyjna resortu pomocy społecznej działająca na zasadach zadania zleconego samorządom w ramach realizowania świadczeń pielęgnacyjno-opiekuńczo-wspierających. Celem artykułu jest przedstawienie funkcjonowania, zakresu pomocy oraz oferty programowej Środowiskowego Domu Samopomocy w Kraśniku jako przykładu dobrych praktyk działających na rzecz osób starszych, niesamodzielnych, niepełnosprawnych na podstawie analizy dokumentów urzędowych (statut, regulamin i roczne sprawozdanie placówki za rok 2020).

Słowa kluczowe: senior; wsparcie społeczne; instytucja wsparcia; integracja społeczna. 